\title{
Study on the Influence of Processing Parameters on Piercing Extrusion Process of Large Diameter Cupronickel Alloy Pipes Using 3D FEM Analysis
}

\author{
Jun Cai, Kuaishe Wang, Bing Zhang, and Wen Wang \\ School of Metallurgical Engineering, Xian University of Architecture and Technology, Xi'an 710055, China \\ Correspondence should be addressed to Jun Cai; caijun0116@163.com
}

Received 22 August 2016; Revised 10 December 2016; Accepted 5 January 2017; Published 2 March 2017

Academic Editor: Katsuyuki Kida

Copyright (C) 2017 Jun Cai et al. This is an open access article distributed under the Creative Commons Attribution License, which permits unrestricted use, distribution, and reproduction in any medium, provided the original work is properly cited.

\begin{abstract}
With the rapid development of the shipping and the power industry, the demand for high-performance cupronickel alloy pipes is greatly increasing. The main processing methods of this alloy include semisolid ingot casting and deformation by hot extrusion. Many defects appear during the hot extrusion process for large diameter cupronickel alloy pipes, which results in considerable problems. Therefore, numerical simulation of hot extrusion for cupronickel alloy pipes before the practical production is of vital significance to properly determine the deformation parameters. In order to obtain the influence of processing parameters on the piercing extrusion process of large diameter cupronickel alloy pipe, metal flowing law under different deformation conditions was simulated and analyzed via employing a 3D FEM code. The results showed that piercing speed had no obvious influence on the cupronickel alloy billet. However, the friction had significant influence on the piercing process of cupronickel alloy billet: with the increase of friction coefficient, the temperature and the load increased.
\end{abstract}

\section{Introduction}

Nowadays, the demand for the high-performance cupronickel alloy pipes is greatly increasing due to the rapid development shipping, power, and sea water desalination industry [1]. Cupronickel alloys have an attractive combination of characteristics in terms of their resistance to corrosion and biofouling, which make them an ideal choice for severely corrosive environments, in particular when a great thermal conductivity is needed $[2,3]$. Hot extrusion is the main deformation method for large diameter cupronickel alloy pipes [4]. However, various defects such as overload (Figure 1(a)) and die crack (Figure 1(b)) can be often found during the hot extrusion process of large diameter pipes, which results in considerable problems, such as long process times, high energy consumption, low product yield, and high cost [5]. Therefore, numerical simulation for hot extrusion process of large diameter cupronickel alloy pipes before the practical production is significant to properly design the deformation parameters.

The producing process of cupronickel alloy pipes includes transportation from furnace $\rightarrow$ upsetting of casting ingots $\rightarrow$ piercing process $\rightarrow$ hot extrusion. The piercing process is an important processing step that affects temperature distribution and the movement of material and, consequently, the mechanical properties of the pipes. Therefore, the objective of this research is to investigate the influence of processing parameters on piercing extrusion process of large diameter cupronickel alloy pipe. Toward this end, the finite element package DEFORM 3D is used to simulate the heat transfer during the transportation process and the following piercing extrusion process. The influence of processing parameters on piercing extrusion process of large diameter cupronickel alloy pipe was analyzed from the simulation results.

\section{FEM Simulation Model}

The components of the piercing extrusion die included four parts, piercing mandrel, dummy block, container, and blanking plate, as shown in Figure 2. The billet was cylindrical solid ingot, with a diameter of $440 \mathrm{~mm}$ and a length of $420 \mathrm{~mm}$. Half of the die components and billet are taken as 


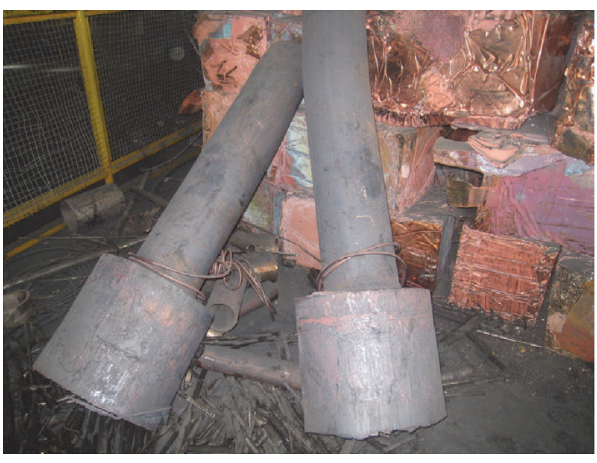

(a)

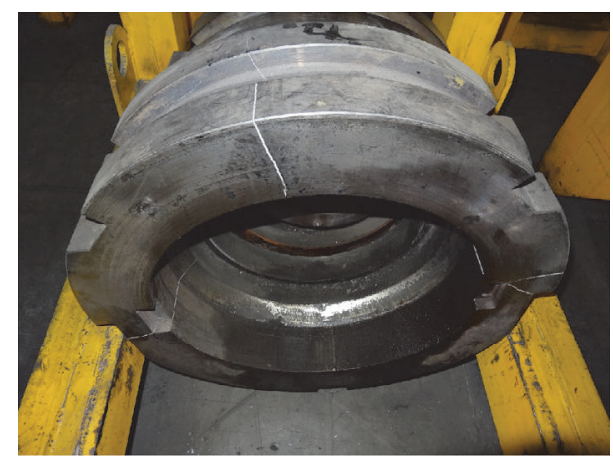

(b)

FIGURE 1: Defect of large diameter cupronickel alloy pipes during hot extrusion: (a) overload; (b) die crack.

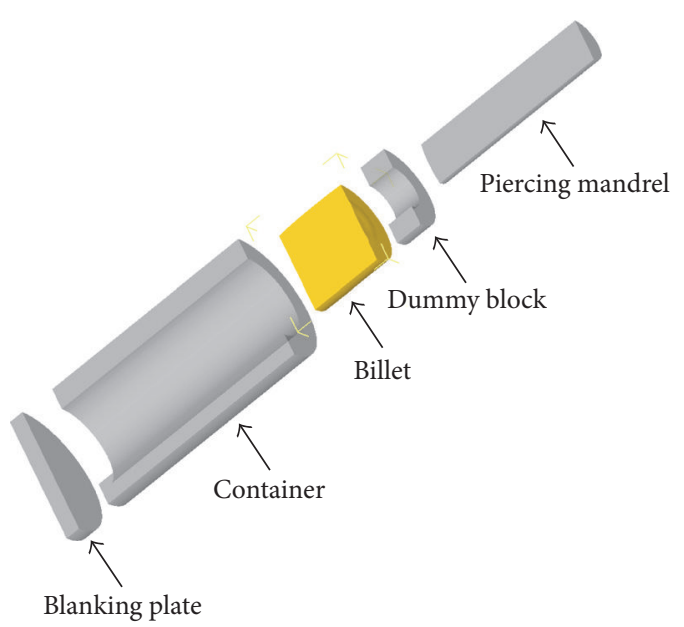

FIGURE 2: Structure components of a piercing extrusion die.

the case to establish 3D FEM model because of their bilateral symmetry structure.

The workpiece material is BFe10-1-2 cupronickel alloy, and its material model is given as follows [6]:

$$
\begin{aligned}
\sigma= & \left(67.5+88.154 \varepsilon^{0.4836}\right) \\
& \cdot \exp [-(0.00315+0.00117 \varepsilon)(T-1073) \\
& +(0.0768+0.000189(T-1073)) \ln \dot{\varepsilon}]
\end{aligned}
$$

where $\sigma$ is the flow stress $(\mathrm{MPa}), \varepsilon$ is true strain, $\dot{\varepsilon}$ is strain rate in $\mathrm{s}^{-1}$, and $T$ is the deformation temperature $(\mathrm{K})$.

The die material is $\mathrm{H} 13$ hot work die steel. The initial temperature of piercing mandrel and dummy block is $400^{\circ} \mathrm{C}$, and the initial temperatures of container, blanking plate, and billet are $400^{\circ} \mathrm{C}, 200^{\circ} \mathrm{C}$, and $950^{\circ} \mathrm{C}$, respectively. Meanwhile, the temperature of ambient environment is regarded as $20^{\circ} \mathrm{C}$. The piercing speeds are 50,80 , and $100 \mathrm{~mm} / \mathrm{s}$, and the friction coefficients are taken to be $0.3,0.5$, and 0.7 .

\section{Results and Discussion}

3.1. Heat Transfer Process. Quadrilateral grids are employed to establish the mesh generation of die and billet mesh, and

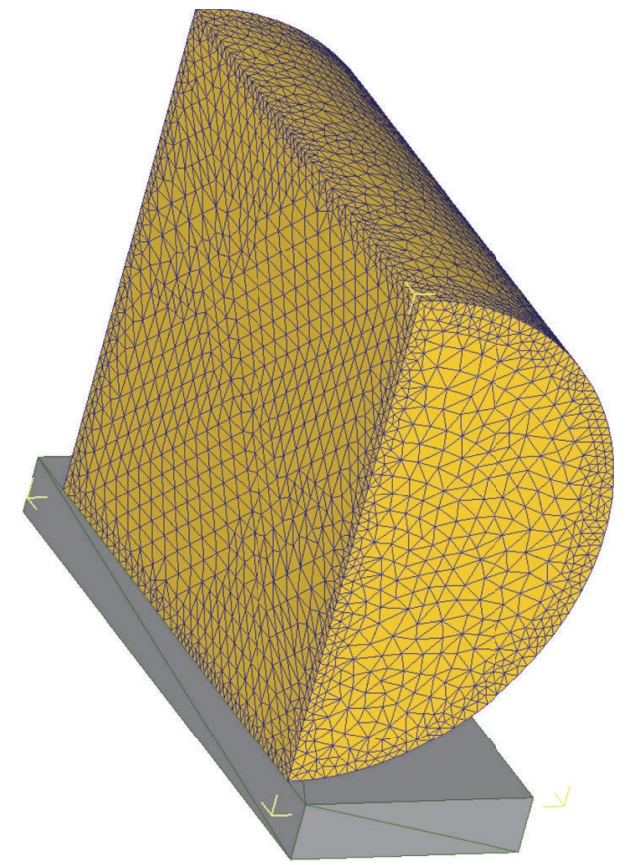

FIGURE 3: Diagram of transportation of billet from furnace to extruder.

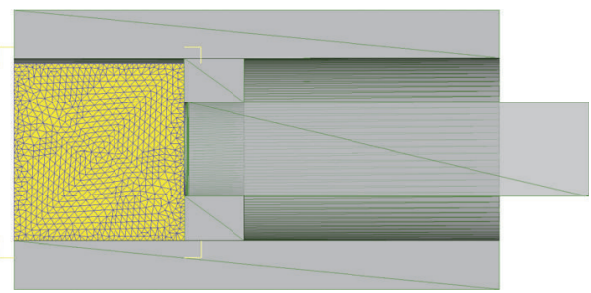

FIgURE 4: Diagram of heat transfer between billet and dies.

the elements number of billet is 37431, as shown in Figures 3 and 4. Lagrangian incremental method is used to solve the deformation simulation. Die displacement is introduced to define the solution step for dynamic analysis, and the step increment is chosen as $3 \mathrm{~mm} / \mathrm{step}$ (lower than $1 / 3$ of minimum side length of the mesh). The heat transfer process 


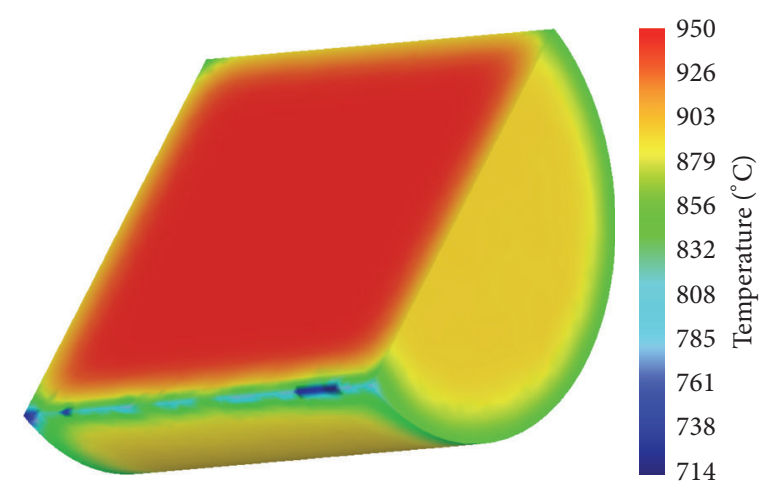

(a)

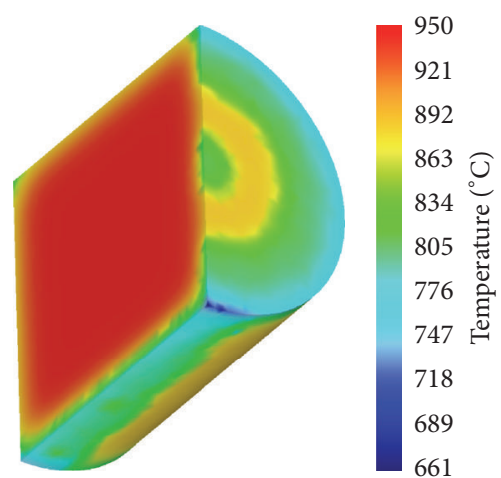

(b)

FIGURE 5: Distribution of temperature field of billet: (a) the first stage (b) the second stage.

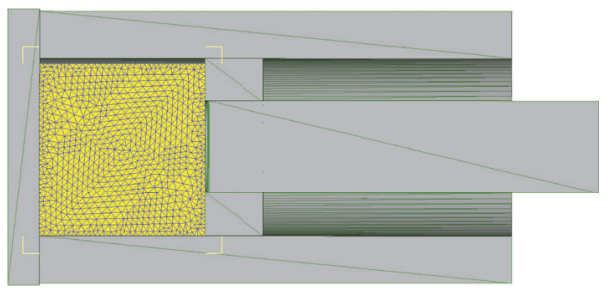

(a)

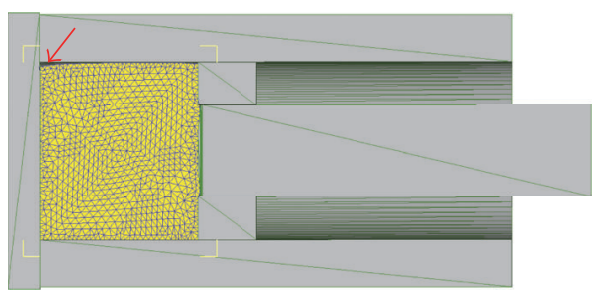

(b)

FIGURE 6: Mesh graph of billet (a) before and (b) after upsetting process.

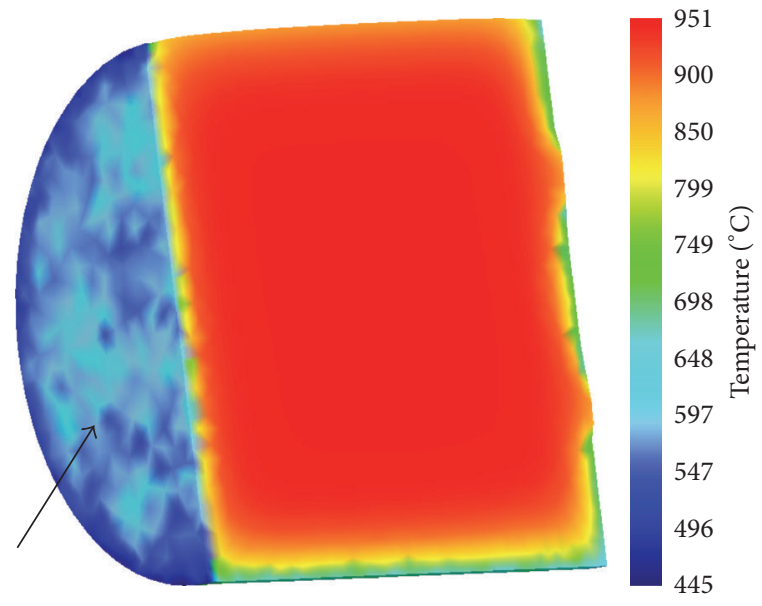

(a)

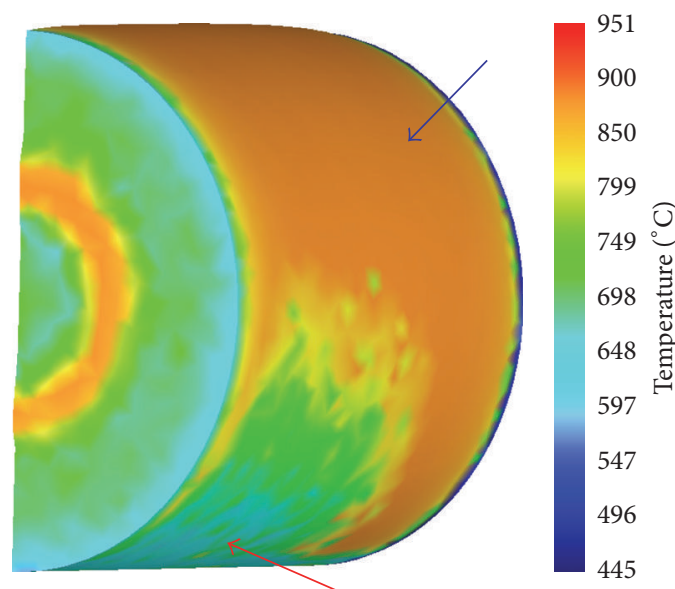

(b)

FIGURE 7: Distribution of temperature field of billet after upsetting.

consists of two stages: (1) contact and convective heat transfer during the transportation process of billet from furnace to extruder (shown in Figure 3) and (2) contact heat transfer between billet and dies in container before the beginning of upsetting process (shown in Figure 4).

The heat transfer time of the first stage is about $45 \mathrm{~s}$, and the temperature distribution of billet is given in Figure 5(a). It can be seen from the figure that the temperature decrease appears only at the surface of billet, and temperature in the center region keeps the initial temperature of $950^{\circ} \mathrm{C}$. The minimum temperature is exhibited in the position of contacting with conveyance (lower than $800^{\circ} \mathrm{C}$ ). The time of the second heat transfer stage is about $15 \mathrm{~s}$, and the distribution of temperature field for billet is illustrated in Figure 5(b). It can be seen from the figure that the maximum temperature is exhibited in the center region of deformation billet and maintains $950^{\circ} \mathrm{C}$.

3.2. Upsetting Process. Figure 6 exhibits the mesh graph of billet before and after upsetting process. The piercing mandrel and dummy block move forward about $20 \mathrm{~mm}$ for the purpose of filling the container. As can be seen from Figure 7, 


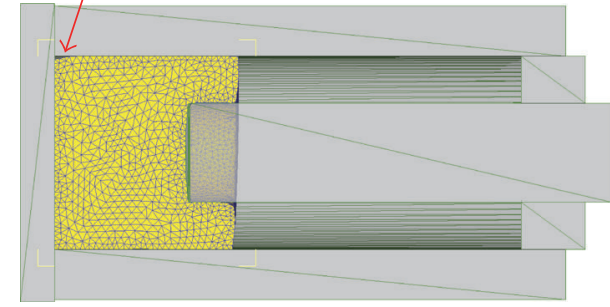

(a)

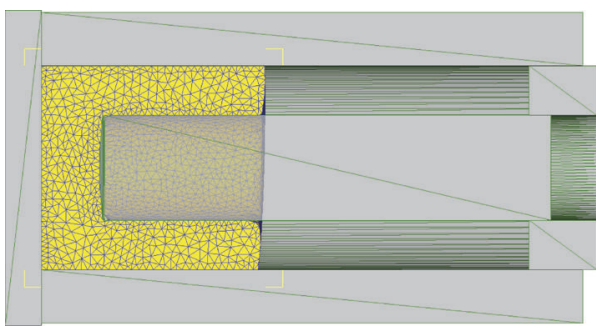

(c)

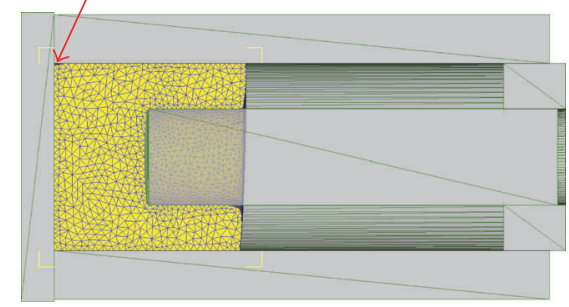

(b)



(d)

Figure 8: Piercing extrusion process at (a) $90 \mathrm{~mm}$, (b) $180 \mathrm{~mm}$, (c) $270 \mathrm{~mm}$, and (d) $360 \mathrm{~mm}$.

there exists obvious clearance between the billet and the upper part of container (red arrows in Figure 6(b)).

The temperature distribution of billet after upsetting process is illustrated in Figure 7. It can be found that the maximum temperature is still located in the center region of billet and keeps initial temperature of $950^{\circ} \mathrm{C}$. The minimum temperature appears at the contact position with blanking plate (black arrow). Obvious temperature decrease exists in some bottom region of billet (red arrow in Figure 7), while outer side region of billet is still higher than $800^{\circ} \mathrm{C}$ (blue arrow). Therefore, only a small part of billet has contacted with container.

3.3. Piercing Extrusion Process. After upsetting process, the piercing mandrel moves forward to start piercing process, and the total stroke of piercing mandrel is about $360 \mathrm{~mm}$. During the simulation process, remeshing procedure can be automatically carried out by the DEFORM 3D software on the basis of mesh deformation. Figure 8 shows the shape variation with different stock of $90 \mathrm{~mm}, 180 \mathrm{~mm}, 270 \mathrm{~mm}$, and $360 \mathrm{~mm}$. As can be seen from figures, there exists obvious between billet top and container at the initial stage of piercing process (red arrows in Figures 8(a) and $8(b)$ ). Then, with the increase of deformation, the clearance gradually disappears, as shown in Figures 8(c) and $8(d)$.

3.3.1. Effect of Speed on the Piercing Result. Figure 9 illustrates the temperature distribution of billet at various piercing speeds with the friction coefficient of 0.3 . The minimum temperature is exhibited at the contact position with blanking plate (red arrow in Figure 9(a)) and is lower than $500^{\circ} \mathrm{C}$. Meanwhile, the maximum temperature is higher than $950^{\circ} \mathrm{C}$, which can be attributed to the inner heat generated by the plastic deformation. Moreover, the maximum temperature is located in middle of the extruded billet, which is higher than that on the surface, as shown in Figure 9. Similar distribution was also reported by Guo et al. [7] in needle piercing extrusion of AISI304 stainless steel pipe.

It should be noted that the temperature field of billets at various piercing speeds shows similar distribution. This may be accounted for the fact that the piercing speed is high (even at $50 \mathrm{~mm} / \mathrm{s}$ ), resulting in the similar distribution of temperature field.

The strain field distribution of billet at various piercing speeds is given in Figure 10. It can be seen from the figure that there is no significant difference among the billets. Highstrain region is located at the position of contacting with piercing mandrel.

The stress field distribution of billet at various piercing speeds is shown in Figure 11. As can be seen from the figure, the stress field exhibits similar distribution at different piercing speeds. The maximum stress is located at the position of contacting with blanking plate (about $200 \mathrm{MPa}$ ).

The load-stroke curves at three piercing speeds are plotted in Figure 12. As shown in Figure 12, a steep increase in the piercing load takes place at the final stage. Meanwhile, the piercing load at the speed of $50 \mathrm{~mm} / \mathrm{s}$ is a little lower than that of the other two speeds. The load curves at the speed of $80 \mathrm{~mm} / \mathrm{s}$ and $100 \mathrm{~mm} / \mathrm{s}$ show little difference, and the loads at all piercing speeds are lower than the maximum capability of device (12 MN).

3.3.2. Effect of Friction on the Piercing Result. Figure 13 shows the temperature distribution of billet at the friction coefficient of 0.5 and 0.7 (piercing speed of $100 \mathrm{~mm} / \mathrm{s}$ ). Compared with Figure 9(c), it can be seen from Figure 13 that the maximum temperature increases with the increase of the friction coefficient. Meanwhile, it can be seen from Figure 13(a) that there exists obvious bulge at the lower part of billet (red arrow), while the bulge is not obvious at the friction coefficient of 0.3 

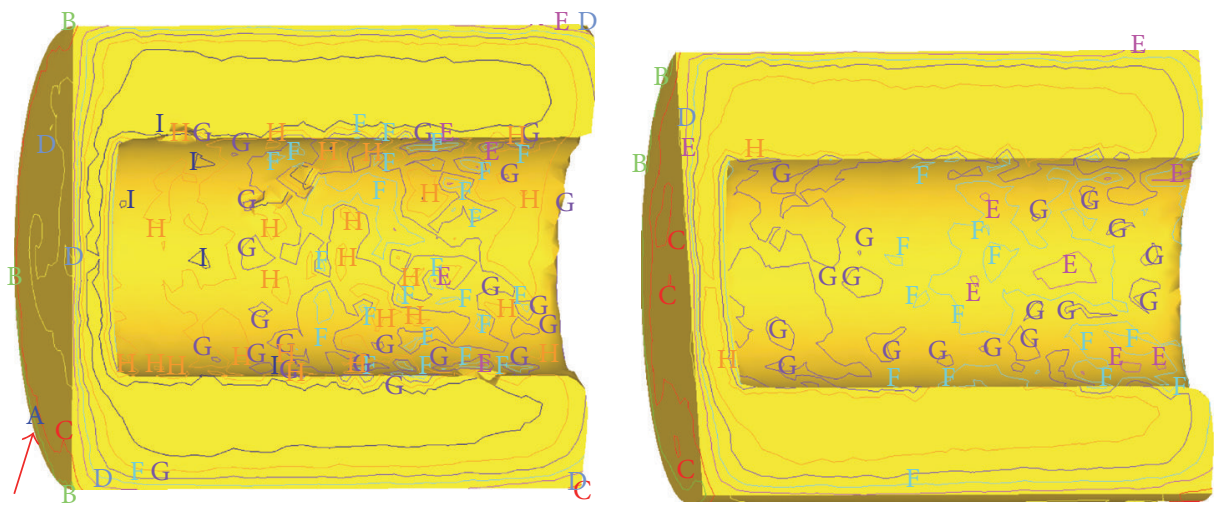

$\begin{array}{ll}\text { Temperature }\left({ }^{\circ} \mathrm{C}\right) & \\ \mathrm{A}=446 & \mathrm{~F}=746 \\ \mathrm{~B}=506 & \mathrm{G}=806 \\ \mathrm{C}=566 & \mathrm{H}=865 \\ \mathrm{D}=626 & \mathrm{I}=925 \\ \mathrm{E}=686 & \mathrm{~J}=985\end{array}$

$\begin{array}{ll}\text { Temperature }\left({ }^{\circ} \mathrm{C}\right) & \\ \mathrm{A}=443 & \mathrm{~F}=788 \\ \mathrm{~B}=512 & \mathrm{G}=857 \\ \mathrm{C}=581 & \mathrm{H}=925 \\ \mathrm{D}=650 & \mathrm{I}=994 \\ \mathrm{E}=719 & \end{array}$

(a)

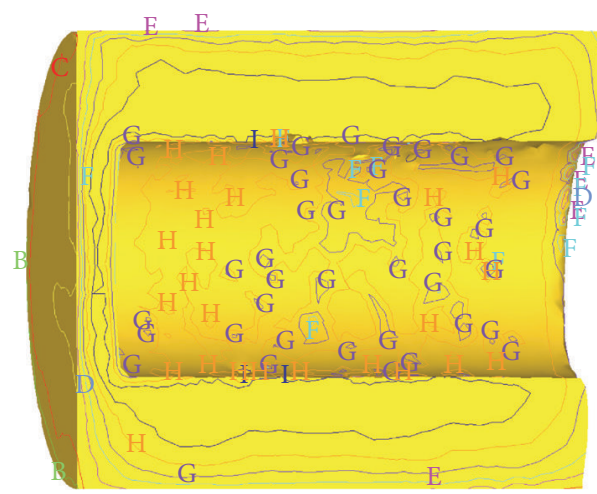

$$
\begin{array}{ll}
\text { Temperature }\left({ }^{\circ} \mathrm{C}\right) & \\
\mathrm{A}=428 & \mathrm{~F}=744 \\
\mathrm{~B}=491 & \mathrm{G}=807 \\
\mathrm{C}=554 & \mathrm{H}=870 \\
\mathrm{D}=617 & \mathrm{I}=933 \\
\mathrm{E}=680 & \mathrm{~J}=996
\end{array}
$$

(c)

Figure 9: Temperature distribution of billet deformed at the piercing speed of (a) $50 \mathrm{~mm} / \mathrm{s}$, (b) $80 \mathrm{~mm} / \mathrm{s}$, and (c) $100 \mathrm{~mm} / \mathrm{s}$.

(shown in Figure 9). When the friction coefficient reaches 0.7, the bulge appears at both lower (red arrow) and upper (blue arrow) parts, as shown in Figure 13(b).

The strain field distribution of billet at various friction conditions is given in Figure 14. It can be seen that there exists unclear difference among the billets (shown in Figures 10(c) and 14), which indicates that the friction has no significant influence on the strain.

The stress field distribution of billet at various friction conditions is given in Figure 15. It can be seen that the maximum stress is still located at the position of contacting with blanking plate. However, the stress at the flank of billet increases quickly with the increase of friction. Therefore, friction has obvious influence on the stress field.
The load-stroke curves at the piercing speeds of $100 \mathrm{~mm} / \mathrm{s}$ with the friction coefficient of $0.3,0.5$, and 0.7 are given in Figure 16. It is clear that friction has significant influence on the loads. With the increase of friction, the load increases sharply. The maximum load of friction coefficient of 0.7 is much higher than $12 \mathrm{MN}$, which indicates that the cupronickel alloy pipes could not be produced under this deformation condition. Meanwhile, the real product of large diameter cupronickel alloy pipes is given in Figure 17.

In order to investigate the effect of mesh convergence on the simulation results, different elements numbers (i.e., various mesh size) are introduced to repeat the simulation process. Figure 17 is the stain field and stress field distribution of billet deformed at the piercing speed of $50 \mathrm{~mm} / \mathrm{s}$ with the 


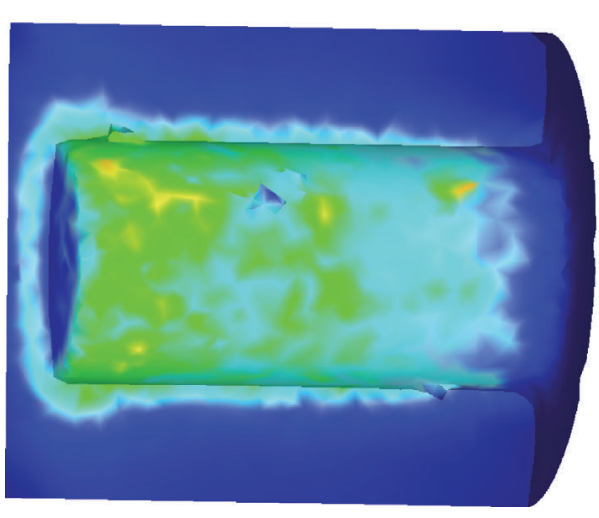

(a)
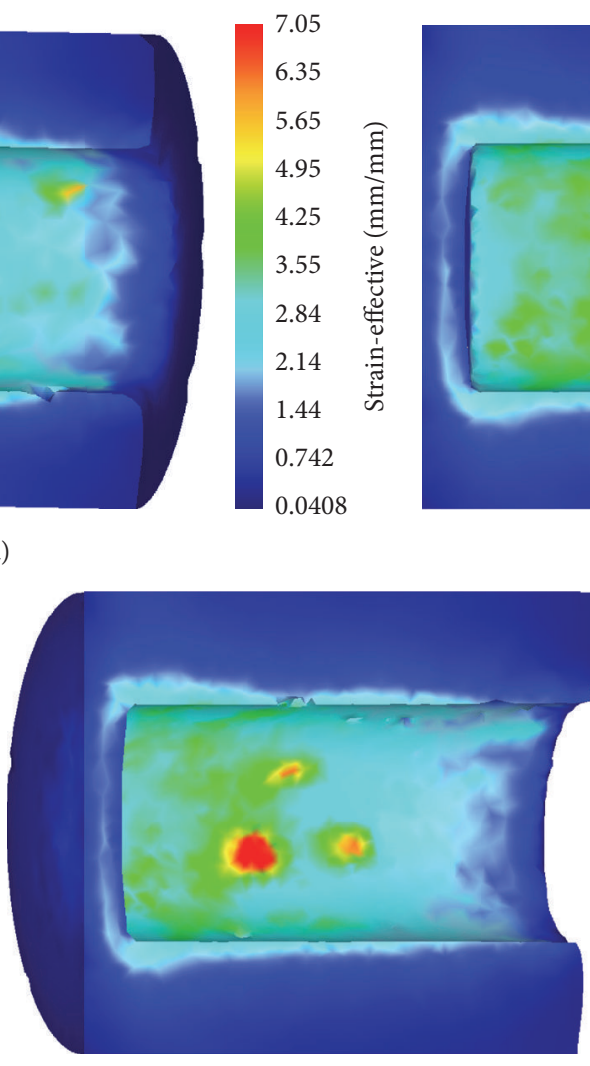

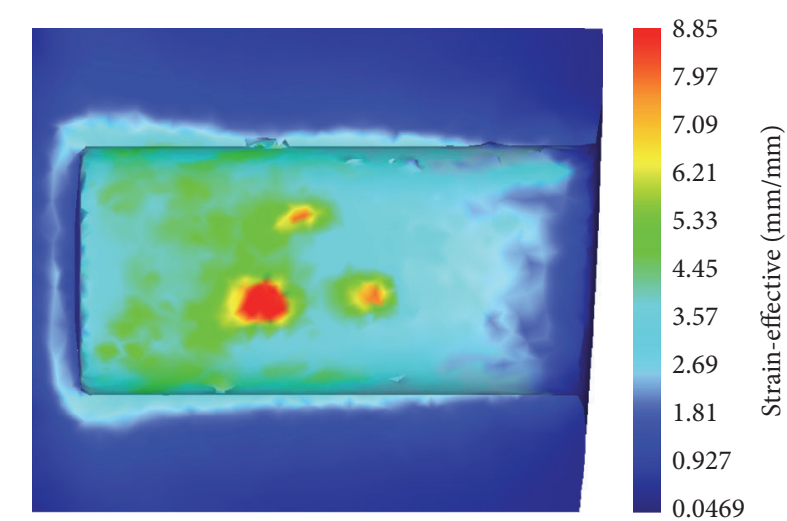

(b)

(c)

FIGURE 10: Strain field distribution of billet deformed at the piercing speed of (a) $50 \mathrm{~mm} / \mathrm{s}$, (b) $80 \mathrm{~mm} / \mathrm{s}$, and (c) $100 \mathrm{~mm} / \mathrm{s}$.

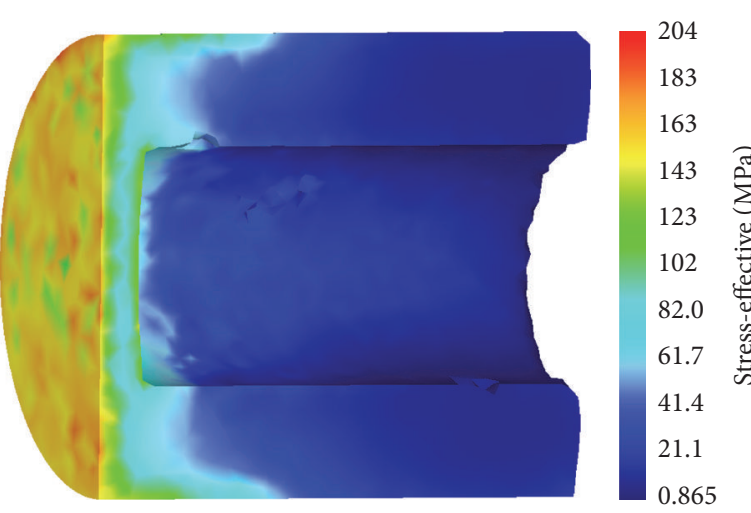

(a)

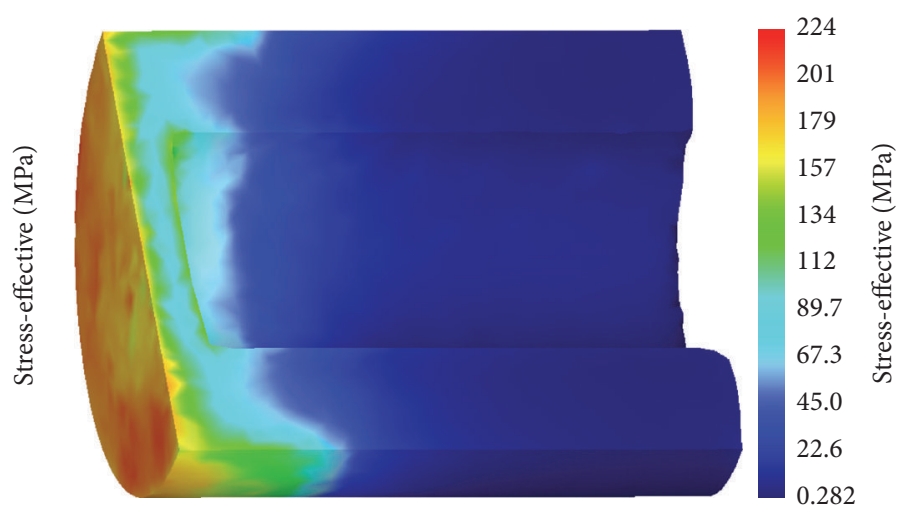

(b)



(c)

FIGURE 11: Stress field distribution of billet deformed at the piercing speed of (a) $50 \mathrm{~mm} / \mathrm{s}$, (b) $80 \mathrm{~mm} / \mathrm{s}$, and (c) $100 \mathrm{~mm} / \mathrm{s}$. 


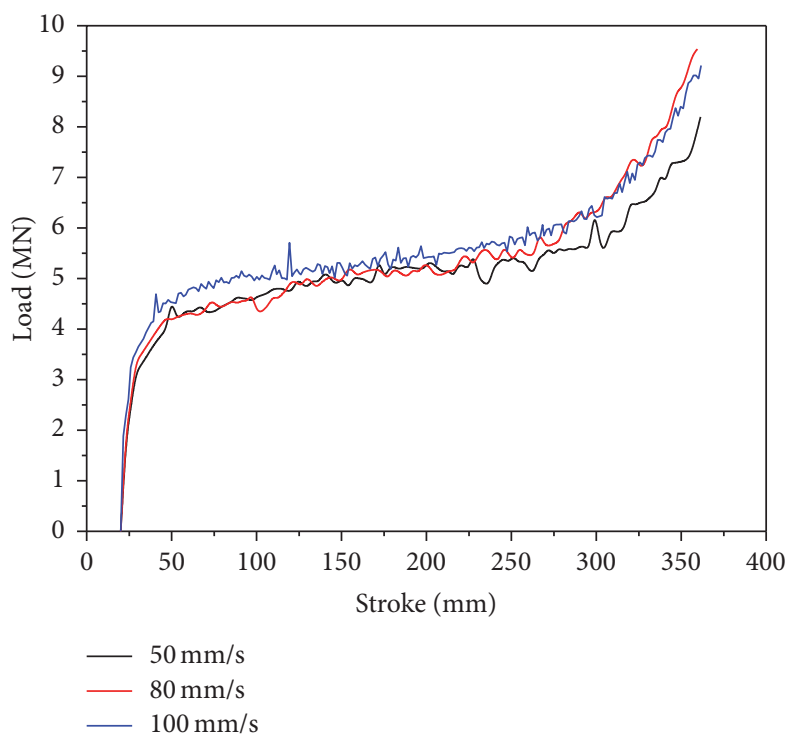

FIGURE 12: Effect of deformation speed on the load-stroke curves.
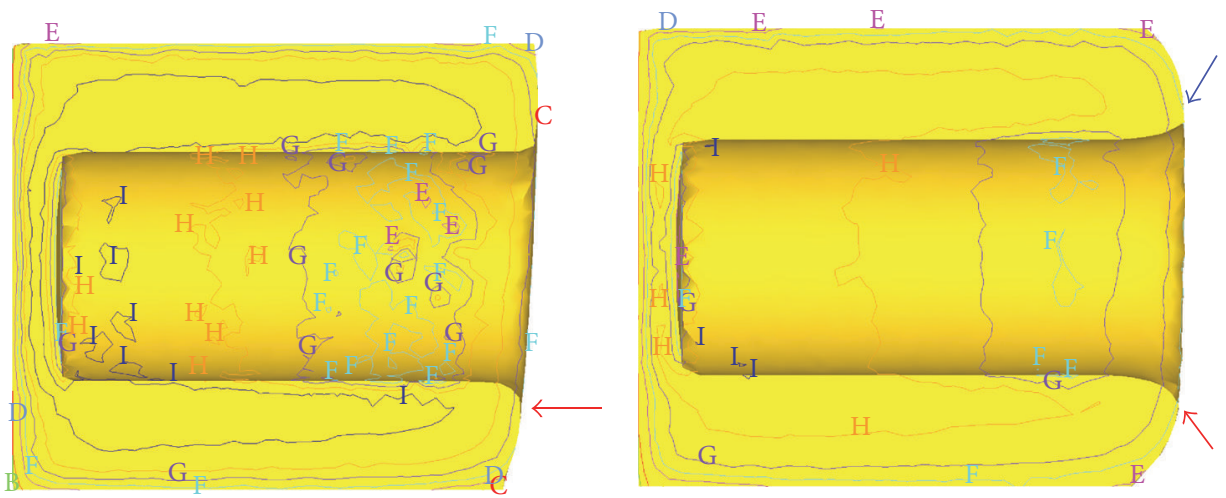

$$
\begin{array}{ll}
\text { Temperature }\left({ }^{\circ} \mathrm{C}\right) & \\
\mathrm{A}=434 & \mathrm{~F}=752 \\
\mathrm{~B}=498 & \mathrm{G}=815 \\
\mathrm{C}=561 & \mathrm{H}=879 \\
\mathrm{D}=625 & \mathrm{I}=942 \\
\mathrm{E}=688 & \mathrm{~J}=1010
\end{array}
$$

$$
\begin{array}{ll}
\text { Temperature }\left({ }^{\circ} \mathrm{C}\right) & \\
\mathrm{A}=436 & \mathrm{~F}=805 \\
\mathrm{~B}=510 & \mathrm{G}=879 \\
\mathrm{C}=583 & \mathrm{H}=952 \\
\mathrm{D}=657 & \mathrm{I}=1030 \\
\mathrm{E}=731 & \mathrm{~J}=1100
\end{array}
$$

(a)

(b)

FIGURE 13: Effect of friction on the temperature distribution of billet at the piercing speed of $100 \mathrm{~mm} / \mathrm{s}$ with friction coefficient of (a) 0.5 and (b) 0.7 .

TABLE 1: Effect of the elements number on the maximum load.

\begin{tabular}{lccc}
\hline Elements number & 30787 & 37431 & 40177 \\
Max load/MN & 8.28 & 8.20 & 8.13 \\
\hline
\end{tabular}

elements number of 30787 (smaller mesh size), and Figure 18 gives the simulation result with the elements number of 40177 (larger mesh size). It can be seen from Figures 17(a) and 18 (a) that the strain field distribution is very similar to that of Figure 10(a). Meanwhile, mesh size has no obvious influence on the stress field distribution of billet, as shown in Figures 11(a), 17(b), and 18(b). Table 1 shows the effect of the elements number on the maximum load. It can be found from the table that the elements number has also small influence on the maximum load. Meanwhile, the real product of large diameter cupronickel alloy pipes is given in Figure 19.

\section{Conclusions}

The piercing extrusion process of large diameter cupronickel alloy pipe at different piercing speeds and friction coefficient 


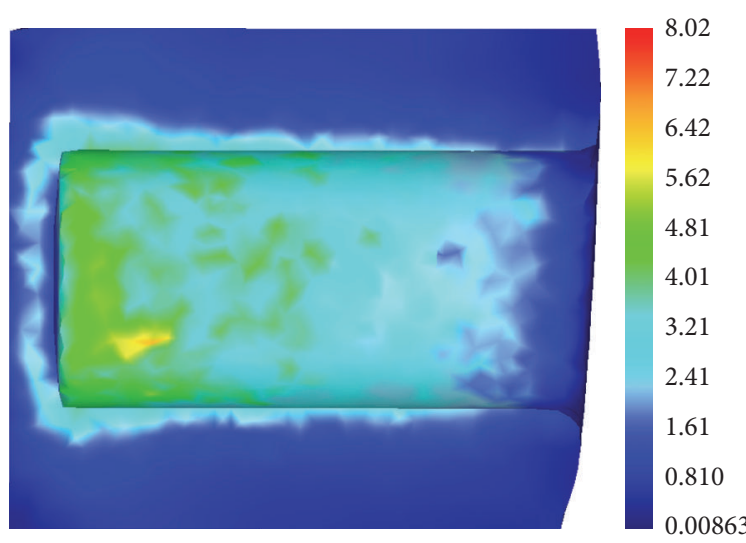

(a)

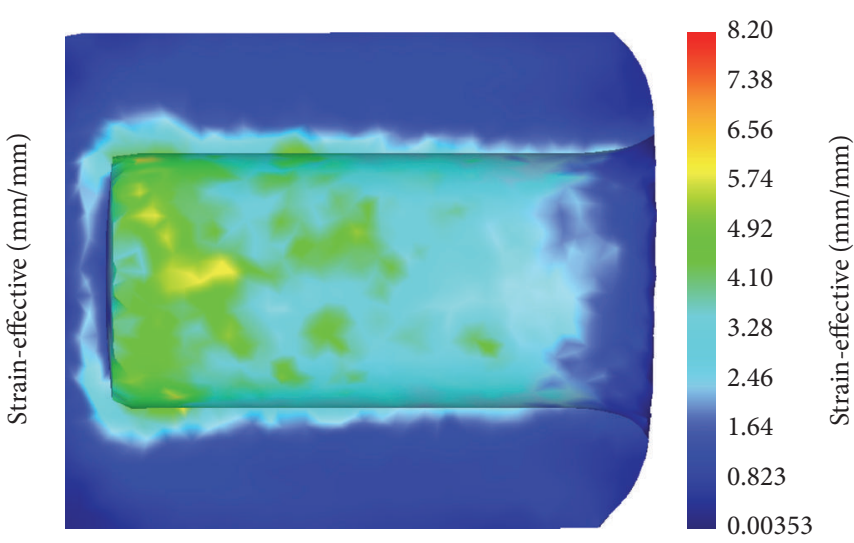

(b)

FIGURE 14: Strain field distribution of billet deformed at the friction coefficient of (a) 0.5 and (b) 0.7.

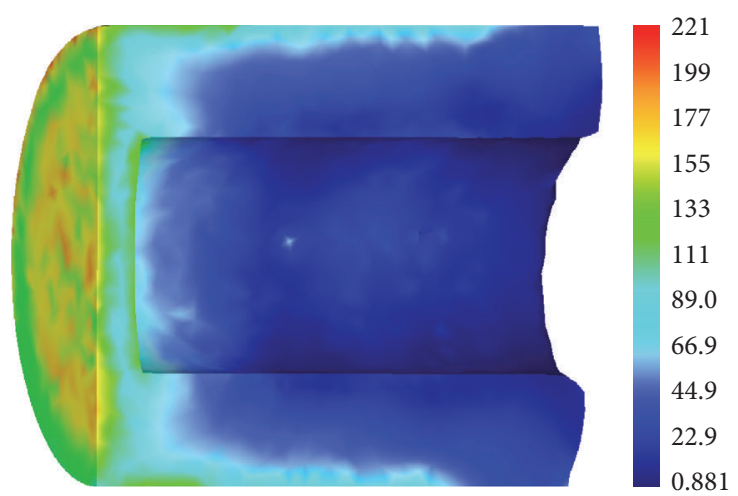

(a)

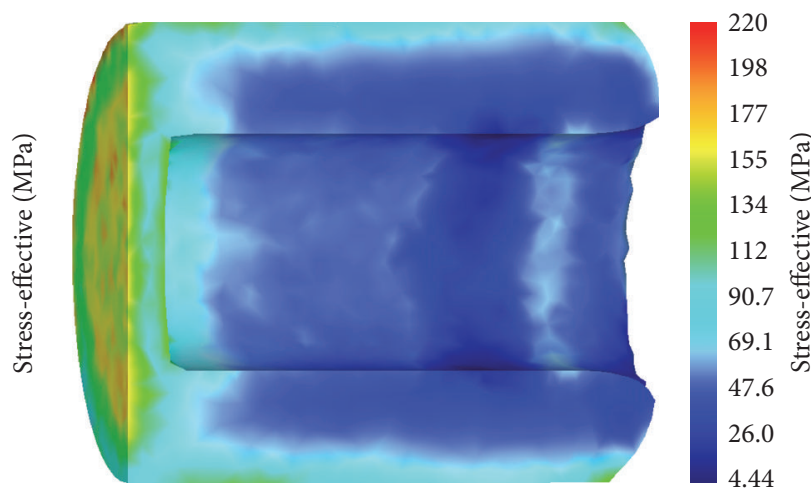

(b)

Figure 15: Stress field distribution of billet deformed at the friction coefficient of (a) 0.5 and (b) 0.7.

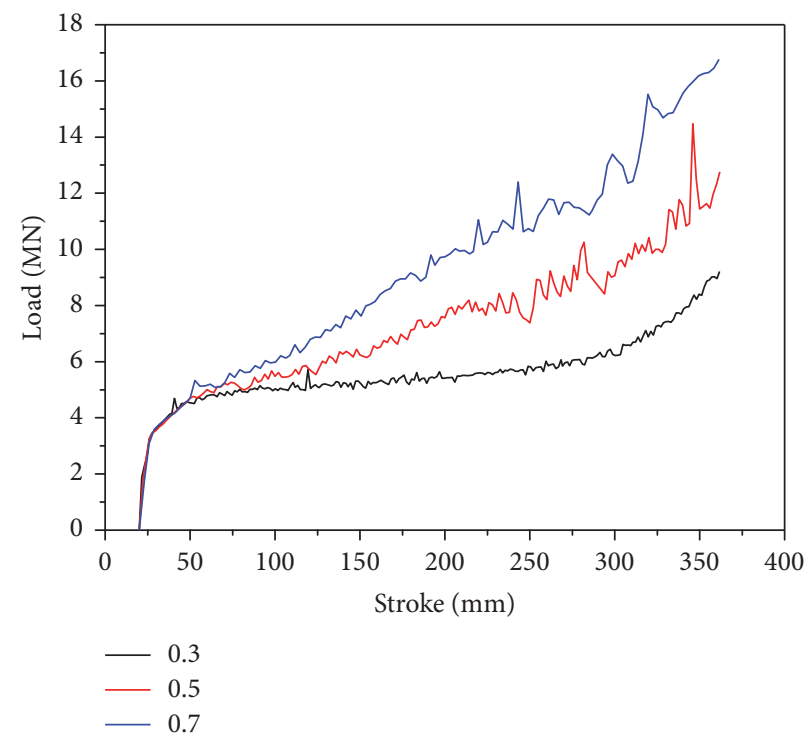

Figure 16: Effect of friction on the load-stroke curves. 




(a)

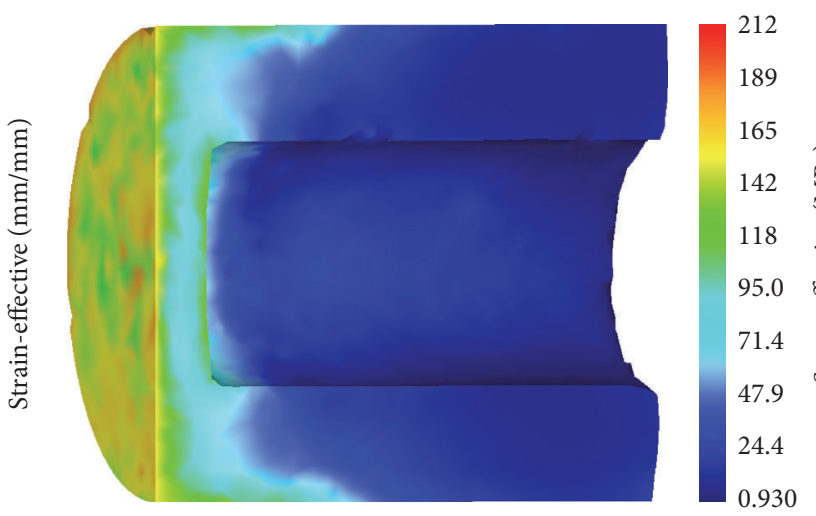

(b)

FIGURE 17: Simulation result of billet deformed with the elements number of 30787: (a) strain; (b) stress.

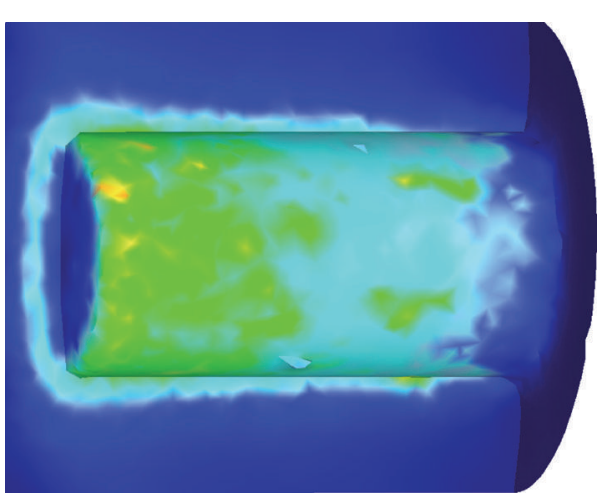

(a)

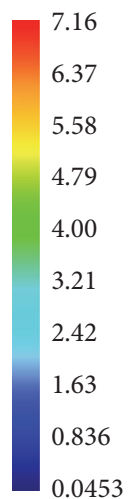

0.0453

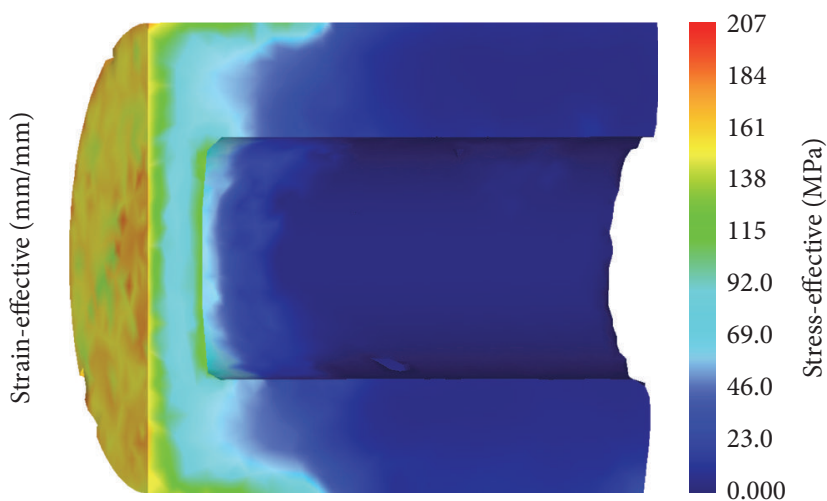

(b)

FIGURE 18: Simulation result of billet deformed with the elements number of 40177: (a) strain; (b) stress.

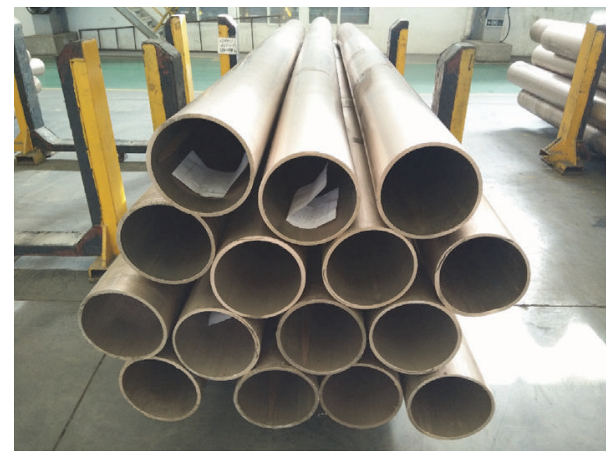

FIGURE 19: Real product of large diameter cupronickel alloy pipes.

was simulated by using a 3D FEM code. The following conclusions are obtained:

(1) Temperature in the center region of billet keeps the initial temperature after transportation and upsetting process.

(2) Piercing speed has no obvious influence on the temperature field, strain field, stress field, and the load-stroke curves.
(3) Friction has significant influence on the billet. With the increase of friction coefficient, the maximum temperature of billet increases, and the load increases sharply.

\section{Competing Interests}

The authors declare that there is no conflict of interests regarding the publication of this paper.

\section{Acknowledgments}

The authors gratefully acknowledge the financial support received from Planned Scientific Research Project of Education Department of Shaanxi Provincial Government (15JS056) and Pre-Research Foundation of Jinchuan Company-Xian University of Architecture and Technology (YY1501).

\section{References}

[1] G. Y. Lin, W. Yang, Y. C. Wan, P. J. Tang, B. Wei, and S. H. Zhang, "Influence of rare earth elements on corrosion resistance 
of BFe10-1-1 alloys in flowing marine water," Journal of Rare Earths, vol. 27, no. 2, pp. 259-263, 2009.

[2] X. Zhu and T. Lei, "Characteristics and formation of corrosion product films of $70 \mathrm{Cu}-30 \mathrm{Ni}$ alloy in seawater," Corrosion Science, vol. 44, no. 1, pp. 67-79, 2002.

[3] S. Cincera, S. Barella, M. Bellogini, and E. Bresciani, "Denickelification of 70/30 cupronickel tubing in a cooling heat exchanger," Journal of Failure Analysis and Prevention, vol. 12, no. 3, pp. 300-304, 2012.

[4] G. Chunlei, L. Xuefeng, H. Haiyou, and X. Jianxin, "Effects of room-temperature deformation on mechanical properties, microstructure and texture of continuous columnar-grained BFe10-1-1 cupronickel alloy tubes," Materials Science and Engineering A, vol. 579, pp. 202-208, 2013.

[5] J. Cai, K. Wang, C. Miao, W. Li, W. Wang, and J. Yang, "Constitutive analysis to predict high-temperature flow behavior of BFe10-1-2 cupronickel alloy in consideration of strain," Materials and Design, vol. 65, pp. 272-279, 2015.

[6] J. Cai, Y. Lei, K. S. Wang, X. L. Zhang, C. P. Miao, and W. B. $\mathrm{Li}$, "A comparative investigation on the capability of modified zerilli-armstrong and arrhenius-type constitutive models to describe flow behavior of BFe10-1-2 cupronickel alloy at elevated temperature," Journal of Materials Engineering and Performance, vol. 25, no. 5, pp. 1952-1963, 2016.

[7] L.-G. Guo, K.-K. Dong, B.-J. Zhang, H. Yang, W.-D. Zheng, and X.-W. Liu, "Dynamic recrystallization rules in needle piercing extrusion for AISI304 stainless steel pipe," Transactions of Nonferrous Metals Society of China, vol. 22, no. 2, pp. s519-s527, 2012. 

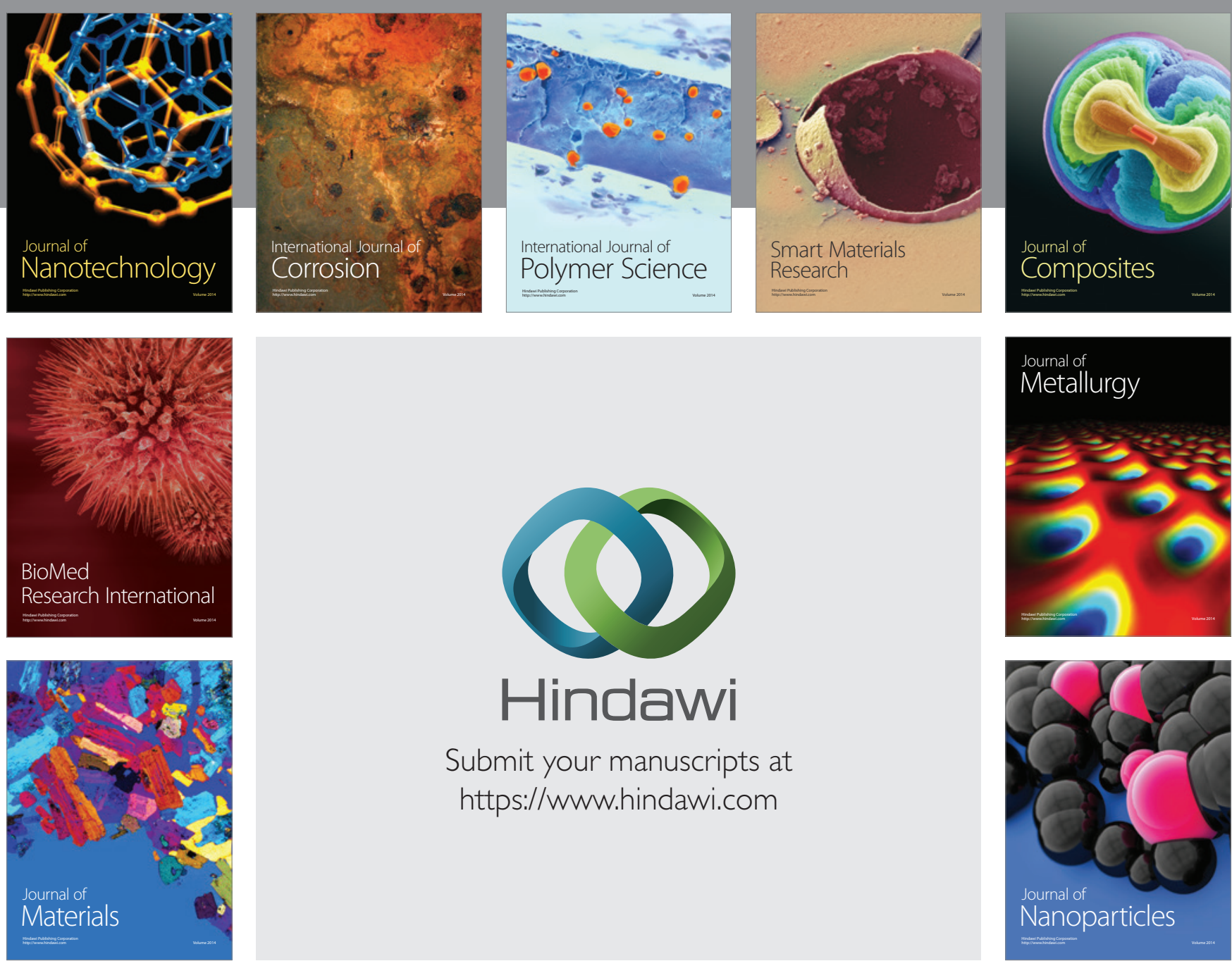

\section{Hindawi}

Submit your manuscripts at

https://www.hindawi.com

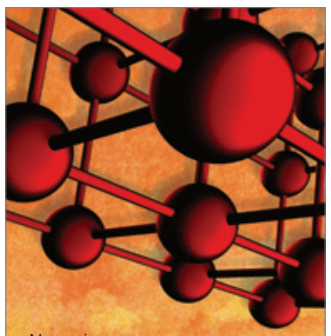

Materials Science and Engineering

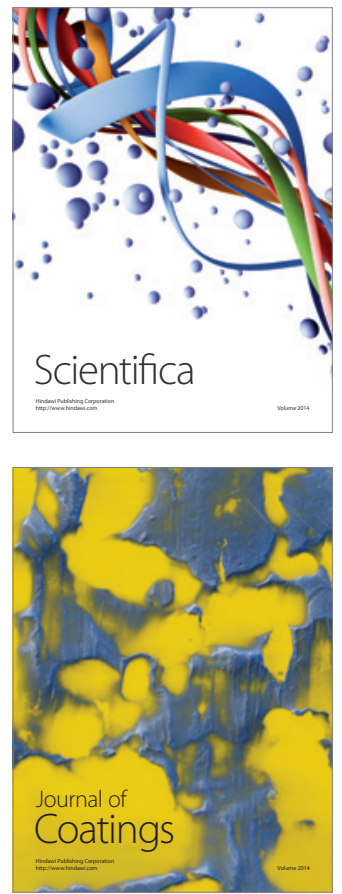


The Scientific World Journal
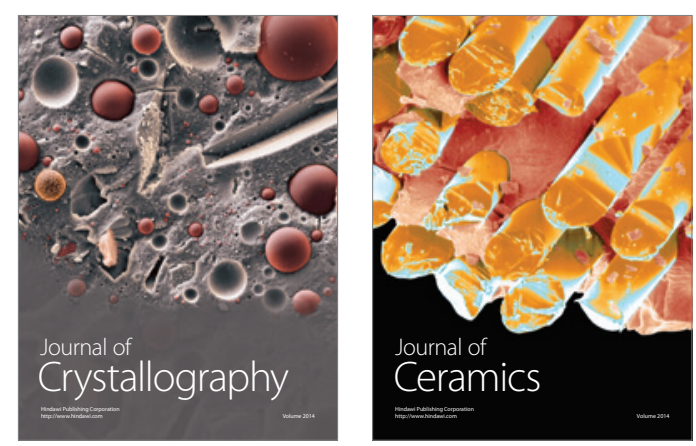
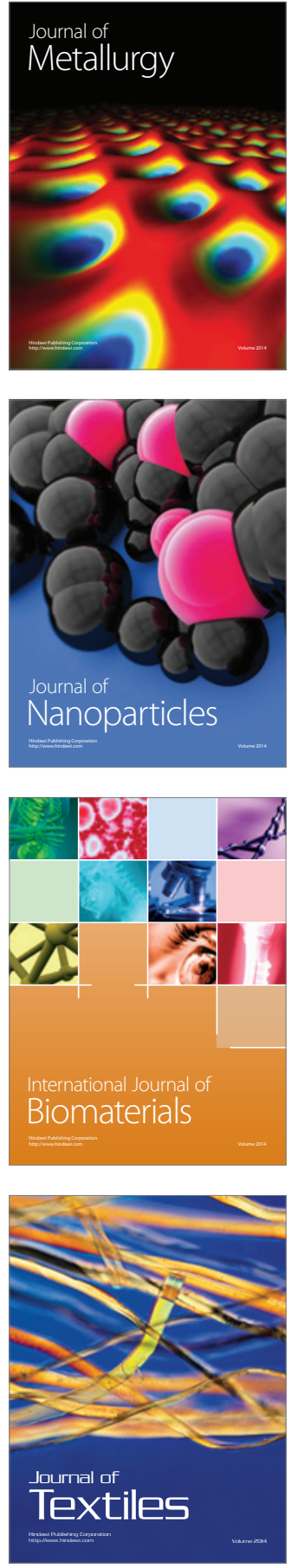